\title{
Use of Residual Biomass from the Textile Industry as Carbon Source for Production of a Low-Molecular-Weight Xylanase from Aspergillus oryzae
}

Gilvan Caetano Duarte ${ }^{1}$, Leonora Rios de Souza Moreira ${ }^{2}$, Diana Paola Gómez-Mendoza ${ }^{3}$, Félix Gonçalves de Siqueira ${ }^{4}$, Luís Roberto Batista ${ }^{5}$, Lourdes Isabel Velho do Amaral ${ }^{6}$, Carlos André Ornelas Ricart ${ }^{3}$ and Edivaldo Ximenes Ferreira Filho ${ }^{2, *}$

1 Laboratory of Genetics and Biochemistry, Biological Sciences Course, Federal University of Tocantins, Porto Nacional, TO, CEP 77500-000, Brazil

2 Laboratory of Enzymology, Department of Cellular Biology, University of Brasília, Brasília, DF, CEP 70910-900, Brazil

3 Laboratory of Biochemistry and Protein Chemistry, Department of Cellular Biology, University of Brasília, Brasília, DF, CEP 70910-900, Brazil

4 Laboratory of Industrial Microbiology and Enzymology, Multidisciplinary Institute for Health, Federal University of Bahia, Vitoria da Conquista, BA, CEP 45029-094, Brazil

5 Laboratory of Food Microbiology, Department of Food Science, Federal University of Lavras, Lavras, MG, CEP 37200-000, Brazil

6 Laboratory of Plant Physiology, Department of Botany, University of Brasília, Brasília, DF, CEP 70910-900, Brazil

* Author to whom correspondence should be addressed; E-Mail: eximenes@unb.br; Tel.: +55-613-107-2976; Fax: +55-613-107-2904.

Received: 18 September 2012; in revised form: 12 October 2012 / Accepted: 12 October 2012 / Published: 23 October 2012

\begin{abstract}
Pretreated dirty cotton residue (PDCR) from the textile industry was used as an alternative carbon source for the submerged cultivation of Aspergillus oryzae and the production of xylanases. The filtered culture supernatant was fractionated by ultrafiltration followed by three chromatographic steps, which resulted in the isolation of a homogeneous low-molecular-weight xylanase (Xyl-O1) with a mass of $21.5 \mathrm{kDa}$ as determined by sodium dodecyl sulfate-polyacrilamide gel electrophoresis (SDS-PAGE) co-polymerized with $0.1 \%$ oat spelt xylan. Enzyme catalysis was the most efficient at $50{ }^{\circ} \mathrm{C}$ and $\mathrm{pH}$ 6.0. The $\mathrm{K}_{\mathrm{m}}$ values $\left(\mathrm{mg} \cdot \mathrm{mL}^{-1}\right)$ for the soluble fraction of oat spelt and birchwood xylans were 10.05 and 3.34, respectively. Xyl-O1 was more stable in the presence of 5,5-dithio-bis-(2-
\end{abstract}


nitrobenzoic acid) (DTNB), 1,4-dithiothreitol (DTT), L-cysteine or $\beta$-mercaptoethanol, which increased the rate of catalysis by $40 \%, 14 \%, 40 \%$ or $37 \%$, respectively. The enzyme stability was improved at $\mathrm{pH} 7.0$ in the presence of $20 \mathrm{mM}$ L-cysteine, with the retention of nearly $100 \%$ of the activity after $6 \mathrm{~h}$ at $50{ }^{\circ} \mathrm{C}$. Xyl-O1 catalyzed the cleavage of internal $\beta-1,4$ linkages of the soluble substrates containing D-xylose residues, with a maximum efficiency of $33 \%$ for the hydrolysis of birchwood xylan after $12 \mathrm{~h}$ of incubation. Identification of the hydrolysis products by high-performance anion exchange chromatography coupled with pulsed amperometric detection (HPAEC-PAD) indicated the predominance of the hydrolysis products X2-X6 during the first $12 \mathrm{~h}$ of incubation and the accumulation of higher xylooligomers after the elution of the last xylooligomer standard, xylohexaose.

Keywords: agro-industrial residues; hemicellulose; enzyme purification; xylanase; hydrolysis

\section{Introduction}

Agricultural and forestry residues, municipal solid waste, industrial processing residues and energy crops are readily available, low-cost sources of large quantities of holocellulose materials that can be used to obtain chemical feedstocks, biofuels, foods and feeds [1,2]. Dirty cotton residue is produced during cotton processing and when harvested cotton is brought to spinners where it is processed into yarn for weaving. The bales that are unsuitable for yarn processing comprise cotton powder, brittle fibers and large quantities of cotton plant waste, such as stalks, stems, leaves and seed hulls, and are referred to as dirty cotton residue. This dirty cotton residue is marketed to re-processing industries to produce new, second-quality cotton fibers and filter cotton powder [3].

Biotechnological use of lignocellulosic residues, including dirty cotton residue, requires the action of enzymes that degrade cellulose, hemicellulose and pectin [4,5]. The enzymes that catalyze these reactions are generally obtained from microorganisms that contain synergistic, multi-catalyst systems [6]. The utilization of abundant, low-cost agricultural by-products as substrates for xylanase production substantially reduces enzyme production costs [7].

$\beta$-Xylanase (1,4- $\beta$-D-xylan xylanohydrolase, EC 3.2.1.8) is a representative of an important group of endo-glycosyl hydrolases. It catalyzes the breakdown of $\beta-1,4$ glycosidic bonds in xylan, a linear polymer of $\beta$-D-xylopyranosyl units [8], to yield short xylooligomers [9]. Xylooligomers are further hydrolyzed into single xylose units by side-chain enzymes [10] that are essential for the efficient breakdown of the second most abundant natural polysaccharide in hardwoods and softwoods, [11]. The xylanases of microorganisms have a number of major biotechnological applications, including clarifying fruit juices and wines, food processing in combination with cellulases, improvement of the nutritional properties of agricultural silage, grain feed and poultry feed, degumming of plant fibers, and bio-pulping [7]. The use of low-molecular-weight xylanases in prebleaching of cellulose pulp has become an alternative approach in eliminating chlorine in bleaching and reducing chlorinated organic compounds in bleach plant effluents. It is worth stressing that their small size may represent an 
advantage for the biobleaching application once the effects of enzymes on pulps depend largely on their penetration into the fibre wall of cellulose pulp.

Numerous reports describe the use of filamentous fungi, primarily those of the Aspergillus genus, in the production of xylanases. Among these fungi, Aspergillus oryzae, the so-called koji mold, has been used extensively in traditional Japanese fermentation products, such as sake (rice wine), shoyu (soy sauce), and miso (soybean paste), for more than 1000 years [12]. The long history of $A$. oryzae in the food fermentation industries prompted the United States Food and Drug Administration (FDA) to include A. oryzae in the list of Generally Recognized as Safe (GRAS) organisms [13]. In addition to its use in the manufacture of fermented foods, A. oryzae is an efficient producer of xylanases.

In light of the biotechnological importance of xylanases in plant cell wall degradation, this study aimed to use pretreated dirty cotton residue (PDCR) as a carbon source for A. oryzae cultivation and the subsequent production and purification of a low-molecular-weight xylanase. Some biochemical properties, such as $\mathrm{pH}$, optimum temperature, thermal stability, and hydrolysis activity, are compared with other xylanolytic enzymes described in the literature. This report is the first on the purification and characterization of a xylanase produced by $A$. oryzae grown on textile industry residue.

\section{Experimental Section}

\subsection{Feed Residue, Substrate and Chemicals}

Dirty cotton residue was kindly supplied by Hantex (Textile Waste Co., Blumenau, Santa Catarina, Brazil). Microcrystalline cellulose (avicel) was obtained from Fluka (Seelze, Germany). Other chemicals were purchased from Sigma Chemical Co. (St. Louis, MO, USA).

All the experiments described below were performed at least three times. The standard deviation of the enzyme assay experiments was less than $20 \%$ of the mean.

\subsection{Residue Pretreatment}

Dirty cotton residue was thoroughly washed with tap water and autoclaved at $121{ }^{\circ} \mathrm{C}$ for $2 \mathrm{~h}$. After autoclaving, it was dried at $65{ }^{\circ} \mathrm{C}$ for $48 \mathrm{~h}$ and then ground to form a homogeneous blend. A fine powder was obtained and used as the substrate for the enzymatic hydrolysis experiments.

\subsection{Organism and Enzyme Production}

$A$. oryzae was isolated from the natural composting of textile wastes and was identified by the Laboratory of Food Microbiology, Lavras, Brazil. The fungus was maintained in PDA medium (2\% potato broth, $2 \%$ dextrose and $2 \%$ agar). For xylanase production, an aliquot $(5.0 \mathrm{~mL})$ of spore suspension $\left(10^{8}\right.$ spores $\left./ \mathrm{mL}\right)$ was inoculated into Erlenmeyer flasks. The cultures were incubated at $28{ }^{\circ} \mathrm{C}$ with constant agitation at $120 \mathrm{rpm}$ for six days in $500 \mathrm{~mL}$ liquid medium containing $(w / v) 0.7 \%$ $\mathrm{KH}_{2} \mathrm{PO}_{4}, 0.2 \% \mathrm{~K}_{2} \mathrm{HPO}_{4}, 0.05 \% \mathrm{MgSO}_{4} \cdot 7 \mathrm{H}_{2} \mathrm{O}$, and $0.16 \%\left(\mathrm{NH}_{4}\right)_{2} \mathrm{SO}_{4}$ at $\mathrm{pH} 7.0$, with $1 \%(w / v)$ PDCR as the carbon source. The crude extract obtained from these cultures was centrifuged at $10,500 \mathrm{~g}$ for $10 \mathrm{~min}$ at $20^{\circ} \mathrm{C}$, filtered through a Büchner funnel with filter paper (Whatman No. 1), and stored at $4{ }^{\circ} \mathrm{C}$. 


\subsection{Enzyme Assays}

The xylanase activity was determined by mixing $25 \mu \mathrm{L}$ of enzyme solution with $50 \mu \mathrm{L}$ of oat spelt xylan $\left(10 \mathrm{mg} \cdot \mathrm{mL}^{-1}\right)$ in $50 \mathrm{mmol} \cdot \mathrm{L}^{-1}$ sodium acetate buffer, $\mathrm{pH} 5.0$, at $50{ }^{\circ} \mathrm{C}$ for $30 \mathrm{~min}$, as described by Filho et al. [14]. The release of the reducing sugar was measured using the 3,5-dinitrosalicylic acid (DNS) method [15], and the xylanase activity was expressed as micromoles of reducing sugar released per min per milliliter (IU.mL ${ }^{-1}$ ). The $\beta$-1,3-glucanase, $\beta$-1,4-glucanase and $\beta$-mannanase assays were performed under the same conditions as described above. The activity against filter paper was measured as described by Ghose [16]. $\beta$-Xylosidase, $\alpha$-arabinofuranosidase, $\beta$-glucosidase and $\beta$-mannosidase activities were determined as reported elsewhere [17]. For the kinetics experiments, the soluble and insoluble fractions of oat spelt and birchwood xylans were used as substrates in a concentration range of $6.0-26.7 \mathrm{mg} \cdot \mathrm{mL}^{-1}$. The substrates were prepared as described by Filho et al. [14]. $\mathrm{K}_{\mathrm{m}}$ and $\mathrm{V}_{\max }$ were estimated from the Michaelis-Menten equation with a non-linear regression data analysis program (Enzfitter) [18]. The effect of temperature on Xyl-O1 activity was determined in the temperature range of 30 to $80{ }^{\circ} \mathrm{C}$ in $35 \mathrm{mmol} \cdot \mathrm{L}^{-1}$ sodium acetate buffer, $\mathrm{pH}$ 5.0. To determine the effect of $\mathrm{pH}$ on Xyl-O1 activity at $50{ }^{\circ} \mathrm{C}$, the Xyl-O1 activity in the $\mathrm{pH}$ range of 3.0 to 9.0 was determined. The following buffers were used for these experiments: $50 \mathrm{mmol} \cdot \mathrm{L}^{-1}$ sodium acetate ( $\mathrm{pH} 3.0-6.0), 50 \mathrm{mmol} \cdot \mathrm{L}^{-1}$ sodium phosphate $(\mathrm{pH} 6.5-7.5)$, and $50 \mathrm{mmol} \cdot \mathrm{L}^{-1}$ Tris- $\mathrm{HCl}(\mathrm{pH}$ 7.0-9.0). All buffers, regardless of $\mathrm{pH}$, were adjusted to the same ionic strength with $\mathrm{NaCl}$ [19]. Xyl-O1 stability was determined by pre-incubating the enzyme at $\mathrm{pH} 7.0$ at either 50 or $55{ }^{\circ} \mathrm{C}$. At various time points, aliquots were withdrawn, and the residual activity was measured in the presence of $25 \mathrm{mmol} \cdot \mathrm{L}^{-1}$ sodium acetate, $\mathrm{pH} 6.0$ (ionic strength adjusted with $\mathrm{NaCl}$ ), at $50{ }^{\circ} \mathrm{C}$. Purified xylanase activity was determined in the presence of the metal ions $\mathrm{Ag}^{+}, \mathrm{K}^{+}, \mathrm{Na}^{+}, \mathrm{Co}^{2+}, \mathrm{Ca}^{2+}, \mathrm{Cu}^{2+}$, $\mathrm{Fe}^{2+}, \mathrm{Hg}^{2+}, \mathrm{Mg}^{2+}, \mathrm{Mn}^{2+}, \mathrm{Zn}^{2+}, \mathrm{Al}^{3+}$ and $\mathrm{Fe}^{3+}$ at final concentrations of 1.0 and $10 \mathrm{mmol} \cdot \mathrm{L}^{-1}$. The effects of the reagents $1.0 \mathrm{mmol} \cdot \mathrm{L}^{-1} \mathrm{~N}$-bromosuccinimide (NBS), $2.0 \mathrm{mmol} \cdot \mathrm{L}^{-1}$ 5,5-dithio-bis-(2-nitrobenzoic acid) (DTNB) and 2,2-dithiodipyridine, $5.0 \mathrm{mmol} \cdot \mathrm{L}^{-1}$ L-tryptophan, iodoacetamide, diethyl pyrocarbonate (DEPC), 1-ethyl-3-(3-dimethylaminopropyl)-carbodiimide (EDC) and $\beta$-mercaptoethanol, and $20 \mathrm{mmol} \cdot \mathrm{L}^{-1}$ DTT (1,4-dithiothreitol), L-cysteine and sodium dodecyl sulfate (SDS) were also determined in the presence of $25 \mathrm{mmol} \cdot \mathrm{L}^{-1}$ sodium acetate, $\mathrm{pH} 6.0$ (ionic strength adjusted with $\mathrm{NaCl}$ ), at $50{ }^{\circ} \mathrm{C}$. Prior to these tests, the purified enzyme was added to either the ions or the reagents and pre-incubated for $20 \mathrm{~min}$ at $28{ }^{\circ} \mathrm{C}$. The exception to this was the experiments with $\mathrm{Mn}^{+2}$, which was tested at a final concentration of $20 \mathrm{mmol} \cdot \mathrm{L}^{-1}$ and pre-incubated for $40 \mathrm{~min}$. Appropriate controls were included for all the experiments, and the average values are reported as relative activity (\%). The amino acids L-cysteine and L-tryptophan and the ion $\mathrm{Mn}^{2+}$ interfered with the quantification of the reducing sugars by the DNS assay by $20 \%$ and $40 \%$, respectively, which were corrected to obtain the final value of xylanase activity.

\subsection{Determination of Protein Concentration}

Protein concentration was determined by the Bradford method [20] using a Protein Assay Kit (Bio-Rad Laboratories, Hercules, CA, USA) and bovine serum albumin as the reference protein according to the manufacturer's instructions. 


\subsection{Enzyme Purification}

A sample $(110 \mathrm{~mL})$ of filtered culture supernatant (FCS) was obtained after $A$. oryzae cultivation and was concentrated by ultrafiltration using an Amicon System with a $10 \mathrm{kDa}$ cut-off point membrane (PM-10; Amicon Millipore Co., Billerica, MA, USA). The ultrafiltrate contained approximately $50 \%$ of the xylanolytic activity from the FCS and was subjected to lyophilization (Freeze Dryer Liobrás, Brazil) for $48 \mathrm{~h}$. The lyophilized material was resuspended in $50 \mathrm{mmol} \cdot \mathrm{L}^{-1}$ sodium phosphate buffer, $\mathrm{pH} 7.0$, containing $150 \mathrm{mmol} \cdot \mathrm{L}^{-1} \mathrm{NaCl}$ and $0.02 \% \mathrm{NaN}_{3}$. The solution was then centrifuged at $10,500 \mathrm{~g}$ at $4.0{ }^{\circ} \mathrm{C}$ for $10 \mathrm{~min}$. This supernatant was used in the subsequent chromatographic steps. Aliquots of $4.5 \mathrm{~mL}$ were fractionated by gel filtration chromatography using a Sephacryl S-100 column $(45 \times 2.6 \mathrm{~cm})$ that had been pre-equilibrated with $50 \mathrm{mmol} \cdot \mathrm{L}^{-1}$ sodium phosphate buffer, $\mathrm{pH} 7.0$, containing $150 \mathrm{mmol} \cdot \mathrm{L}^{-1} \mathrm{NaCl}$ and $0.02 \% \mathrm{NaN}_{3}$. The enzyme sample was eluted at a flow rate of $20 \mathrm{~mL} \cdot \mathrm{h}^{-1}$, and $3.0 \mathrm{~mL}$ fractions were collected and analyzed by absorbance at a wavelength of $280 \mathrm{~nm}$. Fractions with xylanolytic activity were pooled, and a combined volume of $6.5 \mathrm{~mL}$ was re-subjected to gel filtration chromatography on a Sephadex G-50 column $(65 \times 2.6 \mathrm{~cm})$ that was pre-equilibrated in the same buffer described above. Fractions were eluted with at a flow rate of $20 \mathrm{~mL} \cdot \mathrm{h}^{-1}$, and $3.0 \mathrm{~mL}$ aliquots containing xylanase activity were collected and pooled. Finally, a volume of $20 \mathrm{~mL}$ that was obtained in the earlier fractionation was pooled and dialyzed at $4.0{ }^{\circ} \mathrm{C}$ overnight against $20 \mathrm{mmol} \cdot \mathrm{L}^{-1}$ sodium phosphate buffer, $\mathrm{pH} 7.0$, with $0.02 \% \mathrm{NaN}_{3}$. The dialyzed volume was subjected to ion exchange chromatography on a Q-Sepharose column $(2.6 \times 4.0 \mathrm{~cm})$ and equilibrated with $20 \mathrm{mmol} \cdot \mathrm{L}^{-1}$ sodium phosphate buffer, $\mathrm{pH} 7.0$, containing $0.02 \% \mathrm{NaN}_{3}$. The column was washed with the same buffer and eluted with a linear gradient of $\mathrm{NaCl}\left(0-1.0 \mathrm{~mol} \cdot \mathrm{L}^{-1}\right)$. The fractions were eluted at a flow rate of $20 \mathrm{~mL} \cdot \mathrm{h}^{-1}$, and $3.0 \mathrm{~mL}$ aliquots containing xylanolytic activity were collected and pooled for further characterization. All chromatographic steps were performed at room temperature.

\subsection{Electrophoresis}

Sodium dodecyl sulfate-polyacrylamide gel electrophoresis (SDS-PAGE) was performed on 12\% gels according to Laemmli [21], and the protein bands were visualized with silver stain [22]. The Low Molecular Weight (LMW) marker (GE Healthcare, Brazil) was used as the standard. Xyl-O1 activity was detected using a zymogram technique with $0.1 \%$ oat spelt xylan as the substrate [23]. In this procedure, a $12 \%$ gel was co-polymerized with oat spelt xylan solution and was stained for xylanase activity in a $0.1 \%$ Congo red solution for $30 \mathrm{~min}$ at room temperature. The gel was then washed with $1.0 \mathrm{~mol} \cdot \mathrm{L}^{-1} \mathrm{NaCl}$ to remove any excess dye and fixed with $0.5 \%$ acetic acid.

\subsection{Measurement of Substrate Specificity}

The Xyl-O1 specificity for the type of glycosidic linkage and glycan moiety, and for soluble versus insoluble xylans, was investigated by monitoring the amount of reducing sugar released when the purified enzyme was incubated with a variety of polysaccharides (oat spelt xylan, birchwood xylan, beechwood xylan, 4-O-methyl-glucurono-D-xylan, CM-cellulose, pectin and mannan) at a final concentration of $6.67 \mathrm{mg} \cdot \mathrm{mL}^{-1}$. The assays were performed under the same conditions as described in 
Section 2.4 for the xylanase assay. Other substrates, such as filter paper and avicel, were used as described in Section 2.4. For the experiments involving $p$-nitrophenylglycosides, the activities of $\beta$-xylosidase, $\alpha$-arabinofuranosidase, $\beta$-glucosidase and $\beta$-mannosidase were determined by measuring the amount of $p$-nitrophenol (PNP) released. The assays were performed at $50{ }^{\circ} \mathrm{C}$ in $50 \mathrm{mmol} \cdot \mathrm{L}^{-1}$ sodium acetate buffer, $\mathrm{pH}$ 6.0, with $p$-nitrophenyl- $\beta$-D-xyloside (PNPX), PNPA ( $p$-nitrophenyl- $\alpha$-Larabinofuranoside), PNPG ( $p$-nitrophenyl- $\beta$-D-glucoside) and PNPM ( $p$-nitrophenyl- $\beta$-D-mannoside) as substrates [17]. The $\beta$-1,3-glucanase activity was measured by mixing $25 \mu \mathrm{L}$ of enzyme solution with $25 \mu \mathrm{L}$ of $1.0 \%$ laminarin as a substrate in $50 \mathrm{mmol} \cdot \mathrm{L}^{-1}$ sodium acetate buffer, $\mathrm{pH} 6.0$. The enzyme mixture was incubated at $45{ }^{\circ} \mathrm{C}$ for $30 \mathrm{~min}$, and the amount of reducing sugar released was determined using the DNS method according to Noronha and Ulhoa [24].

\subsection{Enzymatic Hydrolysis}

Reaction mixtures containing $1 / 3$ purified Xyl-O1 $\left(6.0 \mu \mathrm{g} \cdot \mathrm{mL}^{-1}\right)$ and $2 / 3$ substrate solution (soluble or insoluble birchwood xylans $\left(10 \mathrm{mg} \cdot \mathrm{mL}^{-1}\right)$ prepared according to Filho et al. [14]) were incubated for $6,12,18$ or $24 \mathrm{~h}$ at $28^{\circ} \mathrm{C}$ with agitation at $120 \mathrm{rpm}$ in a final reaction volume of $0.3 \mathrm{~mL}$. Aliquots of $75 \mu \mathrm{L}$ were removed at the specified intervals and analyzed for the amount of total reducing sugars. The xylooligosaccharides released during these intervals were identified and quantified with high-performance anion exchange chromatography coupled with pulsed amperometric detection (HPAEC-PAD) as described previously by Ryan et al. [25]. In this process, $75 \mu \mathrm{L}$ aliquots were boiled for $10 \mathrm{~min}$ at $100{ }^{\circ} \mathrm{C}$, lyophilized and then dissolved in $500 \mu \mathrm{L}$ Milli-Q water. The hydrolysis products were analyzed on a Dionex ICS-3000 Ion Chromatography DC System equipped with a CarboPac PA100 column and guard column with an operating flow rate of $0.25 \mathrm{~mL} \cdot \mathrm{min}^{-1}$ at $28{ }^{\circ} \mathrm{C}$. Samples $(10 \mu \mathrm{L})$ were injected using an AS40 auto sampler (Dionex Co.). The products were eluted for $70 \mathrm{~min}$ using $100 \mathrm{mmol} \cdot \mathrm{L}^{-1} \mathrm{NaOH}\left(50 \%\right.$ solution, Dionex) and a gradient of $0-500 \mathrm{mmol} \cdot \mathrm{L}^{-1}$ sodium acetate (Dionex). The column was re-equilibrated for $15 \mathrm{~min}$ with $100 \mathrm{mmol} \cdot \mathrm{L}^{-1} \mathrm{NaOH}$ solution between successive injections. Xylooligosaccharides were identified with an ED40 Electrochemical Detector (Dionex) and analyzed using Chromeleon 6.8 software (Dionex). Xylooligosaccharides that had a degree of polymerization from 2 to 6 D-xylose units (xylobiose, X2; xylotriose, X3; xylotetraose, X4; xylopentaose, X5; xylohexaose, X6; Megazyme Co., Wicklow, Ireland) and xylose (X1; $15 \mu \mathrm{g} \cdot \mathrm{mL}^{-1}$ ) were used as standards for the analysis of the reaction products.

\section{Results and Discussion}

\subsection{Enzymatic Characterization of the FCS from Aspergillus oryzae Grown on PDCR}

The enzymatic profiles of the FCS from A. oryzae grown for 6 days at $28{ }^{\circ} \mathrm{C}$ on PDCR are shown in Table 1 . The xylanase and pectinase activity values under these culture conditions were 0.488 and $0.258 \mathrm{IU} \cdot \mathrm{mL}^{-1}$, respectively. The mannanase, CM-cellulase and FPase activities were all approximately $0.100 \mathrm{IU} \cdot \mathrm{mL}^{-1}$. The tests for avicelase activity revealed a residual enzymatic activity with a value close to zero. Based on the data in Table 1, it can be inferred that the use of PDCR as a carbon source for $A$. oryzae cultivation primarily induces hemicellulases, with an emphasis on xylanase production. 
Our results are consistent with those of Siqueira et al. [3], who used agro-industrial residues such as sugarcane bagasse, banana stalks and dirty cotton for the cultivation of various fungi, including A. oryzae, which produced a large amount of xylanase. Other researchers have used lignocellulosic biomass from agro-industrial residues to produce cellulase and xylanase [26-31]. The use of lignocellulosic biomass waste for enzyme production would significantly reduce the cost of enzyme production because the productivities are comparable to those obtained with industrial carbon sources. According to Siqueira et al. [3], agro-industrial residues are cheap carbon sources for the growth of microorganisms, including filamentous fungi, and for the production of hemicellulases. The diversity of hemicellulases produced by $A$. oryzae may be related to the nature of the lignocellulosic biomass components. The untreated dirty cotton residue was subjected to bromatological analysis (results not shown), which indicated that this residue consisted of $56.7 \%$ total fibers and a holocellulose portion (the carbohydrate fraction of lignocellulose) of 75.5\%. The analysis of individual polymers showed that the untreated dirty cotton residue was composed of $65.7 \%$ cellulose, $9.8 \%$ hemicellulose and $6.3 \%$ lignin. The cotton plant fragments were readily apparent in addition to the fibrous profile of this residue.

Table 1. Enzymatic activities of the filtered culture supernatant (FCS) from Aspergillus oryzae grown on pretreated dirty cotton residue (PDCR) for 6 days at $28{ }^{\circ} \mathrm{C}$.

\begin{tabular}{cc}
\hline Enzymatic activity & $\mathbf{I U} \cdot \mathbf{m L}^{-\mathbf{1}}$ \\
\hline Xylanase & $0.488 \pm 0.011$ \\
Pectinase & $0.258 \pm 0.048$ \\
Mannanase & $0.098 \pm 0.006$ \\
CM-cellulase & $0.095 \pm 0.004$ \\
FPase & $0.081 \pm 0.015$ \\
Avicelase & $0.009 \pm 0.001$ \\
\hline
\end{tabular}

\subsection{Xyl-O1 Purification}

Xyl-O1 was purified by ultrafiltration through a PM-10 ultrafiltration membrane, gel filtration chromatography on Sephacryl S-100 and Sephadex G-50 and ion exchange chromatography on Q-Sepharose. In the first step, a xylanase activity of only $0.294 \mathrm{IU} \cdot \mathrm{mL}^{-1}$ was detected in the ultrafiltrate. Because this ultrafiltrate had low protein concentration, the solution was lyophilized prior to chromatography. The chromatographic profiles from the gel filtration columns (results not shown) initially showed that the enzyme sample subjected to chromatography on a Sephacryl S-100 column eluted in two peaks that had xylanase activity. The second peak was selected because it contained a xylanase activity that was approximately 3.5 times higher than the first peak and corresponded to the fractions with the greatest absorbance at $280 \mathrm{~nm}$. The pooled fractions were applied onto a Sephadex G-50 column. The xylanase activity was eluted off this column in a single peak with a low absorbance at $280 \mathrm{~nm}$. An additional peak was eluted with a greater absorbance at $280 \mathrm{~nm}$ and an unidentified colored substance. As shown in Figure 1, fractionation on a Q-Sepharose column revealed that Xyl-O1 eluted before the salt gradient at $\mathrm{pH}$ 7.0. According to Wong et al. [32], there is a conserved relationship between molecular weight and $\mathrm{p} I$ when xylanases from different species are compared. Low-molecular-weight xylanases tend to be basic, whereas high molecular weight is associated with a 
more acidic $\mathrm{p} I$. An exception to this relationship is the Schizophyllum commune xylanase ( $21 \mathrm{kDa}$; $\mathrm{p}$ I 4.5); however, the relationship is conserved even in yeast-like fungi that lack multiple xylanases, e.g., Cryptococcus sp.

Figure 1. Ion exchange chromatography of Xyl-O1 on Q-Sepharose. Absorbance at $280 \mathrm{~nm}$ is represented by closed diamonds [ $\multimap$, xylanase activity is represented by thin Xs $[-*-]$, and the linear gradient $\left(0-1.0 \mathrm{~mol} \cdot \mathrm{L}^{-1} \mathrm{NaCl}\right.$ in equilibration buffer $)$ is represented by a solid line [ $[-]$.

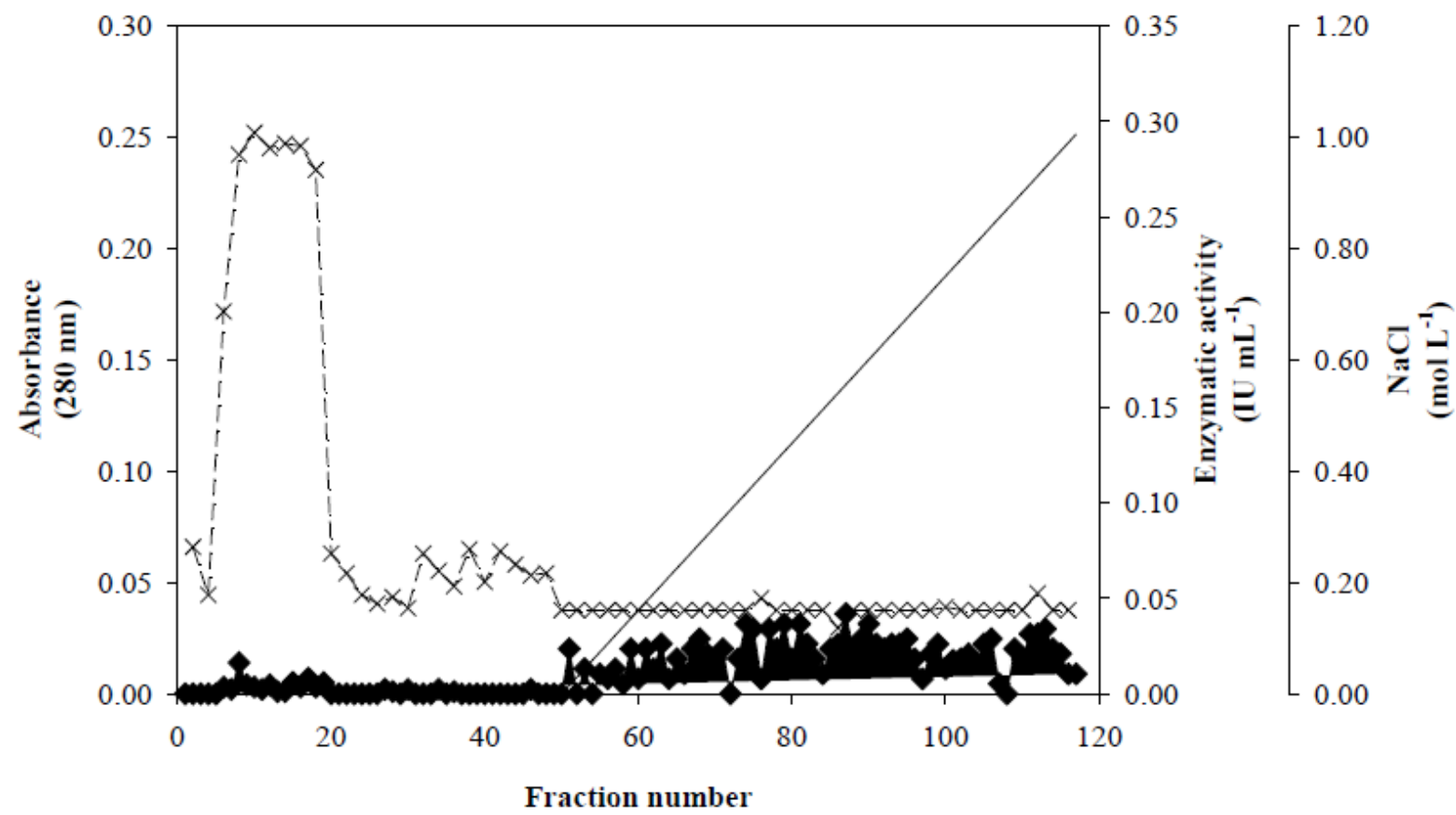

Table 2. Summary of purification of Xyl-O1.

\begin{tabular}{ccccccc}
\hline Purification steps & $\begin{array}{c}\text { Total } \\
\text { volume } \\
(\mathbf{m L})\end{array}$ & $\begin{array}{c}\text { Total } \\
\text { protein } \\
(\mathbf{m g})\end{array}$ & $\begin{array}{c}\text { Total } \\
\text { activity } \\
(\mathbf{I U})\end{array}$ & $\begin{array}{c}\text { Specific } \\
\text { activity } \\
\left(\mathbf{I U} \cdot \mathbf{m g}^{-\mathbf{1}}\right)\end{array}$ & $\begin{array}{c}\text { Purification } \\
(\mathbf{f o l d})\end{array}$ & $\begin{array}{c}\text { Yield } \\
(\%)\end{array}$ \\
\hline Filtered culture supernatant & 110.00 & 5.830 & 53.350 & 9.151 & 1.000 & 100.00 \\
$\quad \begin{array}{c}\text { Ultrafiltrate } \\
\text { Lyophilization }\end{array}$ & 100.00 & 1.500 & 29.400 & 19.600 & 2.142 & 55.11 \\
$\begin{array}{c}\text { Sephacryl S-100 } \\
\text { (fractions 58-64) }\end{array}$ & 4.50 & 0.828 & 1.647 & 1.989 & 0.217 & 3.08 \\
$\quad$ Sephadex G-50 & 21.00 & 0.441 & 7.833 & 17.762 & 1.941 & 14.68 \\
$\begin{array}{c}\text { (fractions 71-84) } \\
\text { Q-Sepharose FF }\end{array}$ & 40.00 & 0.080 & 9.880 & 123.500 & 13.496 & 18.52 \\
(fractions 7-18) & 36.00 & 0.036 & 8.928 & 248.000 & 27.101 & 16.74 \\
\hline
\end{tabular}

* Specific activity $\left(\mathrm{IU} \cdot \mathrm{mg}^{-1}\right.$ ) was determined with soluble oat spelt xylan as substrate.

As noted in Table 2, the xylanolytic activity remaining in the ultrafiltrate portion after lyophilization was considerably recovered during fractionation using gel filtration and ion exchange chromatography. In addition, Table 2 also shows Xyl-O1 purification and yield values of $27.1 \%$ and $16.7 \%$, respectively. These values are consistent with other studies involving xylanase purification in 
which the recovery was low [33-36]. The ultrafiltration procedure retained most of the $\beta$-xylanase activity in the concentrate. The absence of other isoforms or isoenzymes of xylanase in the ultrafiltrate portion, which act synergistically in the hydrolysis of the substrate, may have underestimated the purification and yield values during the final fractionation step [14].

However, our fractionation method, beginning with protein concentration by lyophilization, resulted in higher purification and yield compared to other fractionation methods that are initiated by precipitation with $\left(\mathrm{NH}_{4}\right)_{2} \mathrm{SO}_{4}$ (results not shown). However, the total xylanase activity of the ultrafiltrate (29.400 IU) was significantly reduced to $1.647 \mathrm{IU}$ after the lyophilization step. This finding suggests the presence of xylanase inhibitors that were produced as a result of PDCR degradation and that were also concentrated during the lyophilization step. According to Panagiotou and Olsson [37], the lignin derivatives (furans, phenols and low-molecular-weight acids) that are found in the hydrolysate of pretreated wheat straw inactivated both a mixture of commercial enzymes and a crude enzyme sample from Penicillium brasilianum IBT 20888 during the enzymatic digestion of filter paper and xylan. The purification procedures provided an apparently homogeneous preparation of xylanase activity from $A$. oryzae. An increase in the specific activity from $9.15 \mathrm{IU} \cdot \mathrm{mg}^{-1}$ in the FCS to $248 \mathrm{IU} \cdot \mathrm{mg}^{-1}$ at the end of chromatography was observed. This is an approximately 27 -fold increase and confirms the efficiency of the Xyl-O1 purification. The apparent purity of the enzyme was demonstrated by SDS-PAGE because under denaturing conditions, the gel showed a single band (Figure 2).

Figure 2. SDS-PAGE (12\%) of purified Xyl-O1. The gel was stained with (A) silver nitrate or (B) $0.1 \%$ Congo red. MW-molecular weight marker (phosphorylase b (97 kDa), albumin $(66 \mathrm{kDa})$, ovalbumin $(45 \mathrm{kDa})$, carbonic anhydrase $(30 \mathrm{kDa})$, trypsin inhibitor (20.1 kDa), and $\alpha$-lactalbumin (14.4 kDa)); Lane 1-FCS from Aspergillus oryzae $(10 \mu \mathrm{g})$; Lane 2-Purified Xyl-O1 (5.0 $\mu \mathrm{g})$; Lane 3-FCS from A. oryzae; Lane 4-Purified Xyl-O1.
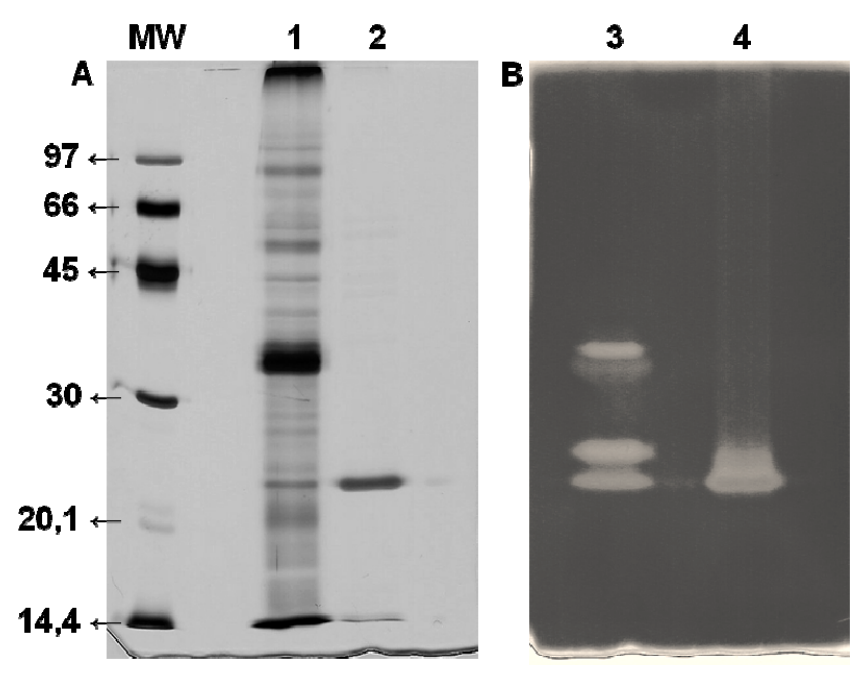

The molecular weight of the purified Xyl-O1 was $21.5 \mathrm{kDa}$, as estimated by the relative migration of the standard markers. A low-molecular-weight xylanase can be useful in pulp bleaching, since smaller enzymes can penetrate further the fiber wall structure and alter more efficiently pulp properties. The molecular weight of Xyl-O1 was also estimated by gel filtration chromatography on 
Sephadex G-50; however, the value was less than $10 \mathrm{kDa}$ (result not shown), suggesting that the enzyme interacted with the matrix. The same phenomenon has been described for $\beta$-xylosidase from Trichoderma harzianum strains [17] and for a low-molecular-weight xylanase from A. fumigatus Fresenius [34]. According to Poutanen [35], the reason for the lower apparent molecular weight that is obtained by gel filtration could be the retarded migration of the enzyme in the gel matrix.

\subsection{Enzyme Characterization}

The xylanase activities of the FCS and purified Xyl-O1 were greatest in the temperature range of 45-60 ${ }^{\circ} \mathrm{C}$ and the $\mathrm{pH}$ range of 5.5 to 6.0 . The two samples were stable in the temperature range of $45-60{ }^{\circ} \mathrm{C}$, with xylanase activity greater than $70 \%$. The greatest FCS activity was observed at $55{ }^{\circ} \mathrm{C}$, and the greatest Xyl-O1 activity was at $50{ }^{\circ} \mathrm{C}$. The two enzyme samples presented the best activity at pH 6.0 in sodium acetate buffer. The activity of the two samples was greater than $90 \%$ in the pH range of 5.5 to 6.0. Other studies involving the purification and characterization of endo- $\beta-1,4$-xylanases from filamentous fungi have indicated that $50{ }^{\circ} \mathrm{C}$ is the most effective temperature for enzyme activity [33,38,39]. Our results are consistent with Kimura et al. [40], who found that the greatest activity for a xylanase, XynG2, that was isolated from a genomic library of A. oryzae KBN616 was at $\mathrm{pH}$ 6.0. However, its greatest enzymatic activity was at $58{ }^{\circ} \mathrm{C}$, and it displayed a different $\mathrm{Km}$ value $\left(5.1 \mathrm{mg} \cdot \mathrm{mL}^{-1}\right)$ on birchwood as the substrate. The $\mathrm{K}_{\mathrm{m}}$ values $\left(\mathrm{mg} \cdot \mathrm{mL}^{-1}\right)$ of Xyl-O1 on a soluble fraction of oat spelt and birchwood xylans were 10.05 and 3.34, respectively. The apparent $\mathrm{K}_{\mathrm{m}}$ values indicated that the purified Xyl-O1 had a preference for birchwood xylan as a substrate. Birchwood xylan contains $90 \%$ xylose, whereas oat spelt xylan contains $75 \%$ xylose, $10 \%$ arabinose and $15 \%$ glucose residues. The preference of Xyl-O1 for substrates containing a higher proportion of D-xylose residues is a relevant property that can be used in the future targeting of this enzyme for alternative methods of cellulose pulp biobleaching.

The Xyl-O1 enzyme activity was reduced to 86 and $8 \%$ in the presence of $\mathrm{Hg}^{2+}$ at concentrations of 1.0 and $10 \mathrm{mmol} \cdot \mathrm{L}^{-1}$, respectively. The same inhibitory effect was observed for $\mathrm{Ag}^{+}$at a concentration of $10 \mathrm{mmol} \cdot \mathrm{L}^{-1}$. The inhibitory effects of $\mathrm{Hg}^{2+}$ and $\mathrm{Ag}^{+}$on xylanase activity are known $[7,25,41,42]$. According to Sandrim et al. [41], the addition of $\mathrm{Hg}^{2+}$ drastically inhibits xylanolytic activity, suggesting the existence of thiol groups in the catalytic site of the enzyme. In general, purified Xyl-O1 remained stable in the presence of most of the ions that we tested. However, $\mathrm{Mn}^{2+}$, which is commonly referred to as an activator of xylanase activity, showed an inhibitory effect at a concentration of $10 \mathrm{mmol} \cdot \mathrm{L}^{-1}$ and promoted a $10 \%$ reduction in activity compared to the control. The same inhibitory effect was observed when the enzyme was pre-incubated for $40 \mathrm{~min}$ at $28{ }^{\circ} \mathrm{C}$ with the same concentration of $\mathrm{Mn}^{2+}$. Conversely, Carmona et al. [43] and Teixeira et al. [39] reported an activating effect of $10 \mathrm{mmol} \cdot \mathrm{L}^{-1} \mathrm{Mn}^{2+}$ on xylanase from A. versicolor and A. awamori $2 \mathrm{~B} .361 \mathrm{U} 2 / 1$. Here, purified Xyl-O1 in the presence of amino acid-modifying reagents and amino acids remained relatively stable or was activated by certain reagents (Table 3 ). The enzyme retained $74 \%$ of its xylanolytic activity in the presence of $20 \mathrm{mmol} \cdot \mathrm{L}^{-1} \mathrm{SDS}$.

The reaction mixture containing $5.0 \mathrm{mmol} \cdot \mathrm{L}^{-1}$ L-tryptophan did not have increased enzymatic activity. However, for compounds containing thiol groups, such as L-cysteine, DTT and $\beta$-mercaptoethanol, the xylanase activity increased by 40,14 and $37 \%$, respectively. The enzyme was 
stable in the presence of NBS and EDC reagents at concentrations of 1.0 and $5.0 \mathrm{mmol} \cdot \mathrm{L}^{-1}$, respectively. However, the enzyme activity was completely inhibited by NBS at a concentration of $10 \mathrm{mmol} \cdot \mathrm{L}^{-1}$ (result not shown). Teixeira et al. [39] also reported the inhibition of xylanase from A. awamori by NBS at the same concentration. NBS is an effective inhibitor of xylanases $[44,45]$ and promotes the oxidation of tryptophan residues that are involved in enzymatic catalysis. Xyl-O1 was slightly inhibited by the alkylating reagent iodoacetamide, indicating the need for thiol groups in catalysis. DEPC and DTP reduced the Xyl-O1 activity by 15 and 12\%, respectively (Table 3 ).

Table 3. Effect of modifying agents and amino acids on the xylanolytic activity of purified Xyl-O1.

\begin{tabular}{|c|c|c|c|}
\hline $\begin{array}{c}\text { Modifying agents or amino } \\
\text { acids }\end{array}$ & Activity $\left(\mathrm{IU} \cdot \mathrm{mL}^{-1}\right)$ & Relative activity (\%) & $\begin{array}{c}\text { Concentration } \\
\left(\mathrm{mmol} \cdot \mathrm{L}^{-1}\right)\end{array}$ \\
\hline $\mathrm{H}_{2} \mathrm{O}$ control & $0.262 \pm 0.021$ & 100.00 & --- \\
\hline $4 \%$ Ethanol control & $0.285 \pm 0.026$ & 100.00 & --- \\
\hline NBS & $0.285 \pm 0.079$ & 108.42 & 1 \\
\hline DTNB * & $0.399 \pm 0.025$ & 140.02 & 2 \\
\hline DTT & $0.300 \pm 0.037$ & 114.35 & 20 \\
\hline L-Cysteine & $0.367 \pm 0.076$ & 140.04 & 20 \\
\hline $\mathrm{H}_{2} \mathrm{O}$ control & $0.290 \pm 0.029$ & 100.00 & --- \\
\hline $4 \%$ Ethanol control & $0.322 \pm 0.006$ & 100.00 & --- \\
\hline DTP * & $0.285 \pm 0.025$ & 88.43 & 2 \\
\hline L-Tryptophan & $0.285 \pm 0.012$ & 98.13 & 5 \\
\hline Iodoacetamide & $0.255 \pm 0.046$ & 87.71 & 5 \\
\hline DEPC & $0.248 \pm 0.037$ & 85.32 & 5 \\
\hline EDC & $0.291 \pm 0.046$ & 100.08 & 5 \\
\hline$\beta$-Mercaptoethanol & $0.397 \pm 0.026$ & 136.68 & 5 \\
\hline $\mathrm{H}_{2} \mathrm{O}$ control & $0.306 \pm 0.031$ & 100.00 & --- \\
\hline SDS & $0.225 \pm 0.025$ & 73.56 & 20 \\
\hline
\end{tabular}

* These compounds were diluted in 4\% ethanol. Enzymatic activity: $0.320 \pm 0.014 \mathrm{IU} \cdot \mathrm{mL}^{-1}$.

The assays investigating the effect of incubation time on Xyl-O1 activity at $\mathrm{pH} 7.0$ revealed that at $50{ }^{\circ} \mathrm{C}$, the enzyme remained active for $5.0 \mathrm{~h}$, retaining $60 \%$ of its activity. Conversely, at $55^{\circ} \mathrm{C}$, the activity decreased to less than $30 \%$ within the first hour of incubation. The thermostability of Xyl-O1 at $50{ }^{\circ} \mathrm{C}$ was greatly increased in the presence of $20 \mathrm{mmol} \cdot \mathrm{L}^{-1} \mathrm{~L}$-cysteine, and the activity remained close to $100 \%$ for an incubation period of $6.0 \mathrm{~h}$ (Figure $3(\mathrm{~A})$ ). At $55{ }^{\circ} \mathrm{C}$, the xylanase activity was enhanced in the presence of L-cysteine and remained stable for $1.0 \mathrm{~h}$, with the catalytic activity remaining greater than $75 \%$ (Figure 3(B)). 
Figure 3. Effect of $20 \mathrm{mmol} \cdot \mathrm{L}^{-1} \mathrm{~L}$-cysteine on the thermostability of purified Xyl-O1 at $\mathrm{pH} 7.0$ and (A) $50{ }^{\circ} \mathrm{C}$ or $(\mathbf{B}) 55^{\circ} \mathrm{C}[-\nabla-]$. The control without L-cysteine [ - ]

(A)

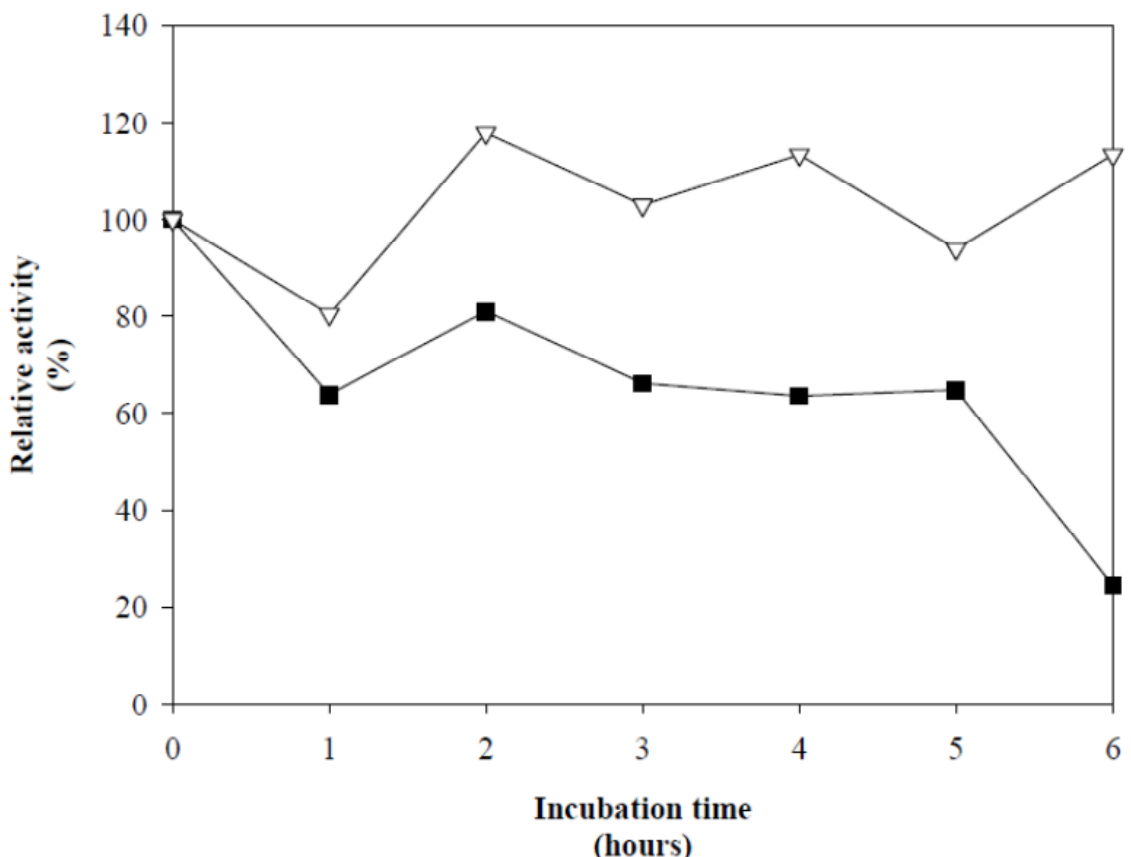

(B)

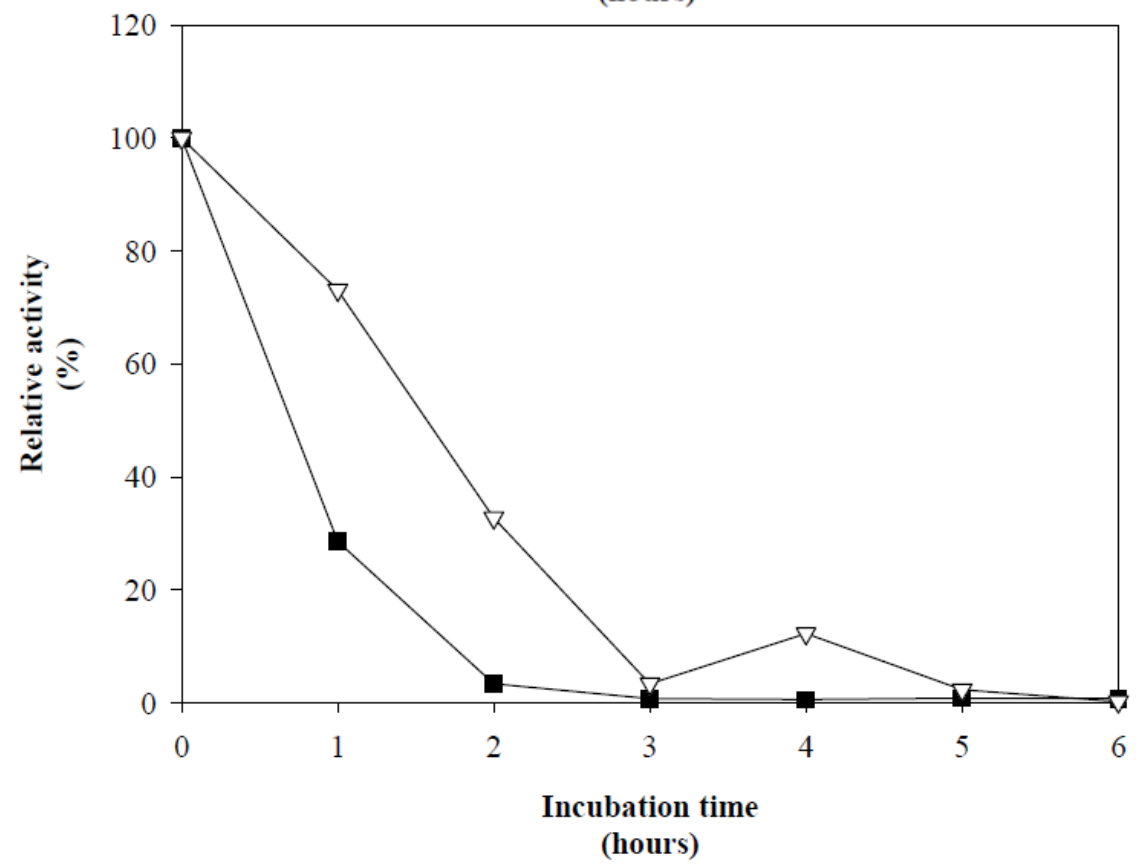

The purified Xyl-O1 efficiently hydrolyzed the substrates that contained D-xylose residues, especially the soluble fraction of oat spelt and the birchwood and beechwood xylans (Table 4). These results suggest that Xyl-O1 is a potential candidate for the pulp bleaching processes, whereas the application of xylanases in the pulp and paper industry requires a cellulase-free activity $[8,11,41,46]$. However, the enzyme activity was significantly reduced in the insoluble fractions of the same substrates, especially for oat spelt xylan, which had a relative activity of less than $1.0 \%$. The enzyme also showed a hydrolysis efficiency of $49.87 \%$ when tested with $4-O$-methyl-glucurono-D-xylan as the substrate. The relative activities for the birchwood and beechwood xylans were 85 and $84.4 \%$, respectively (Table 4). The residual activity was less than $10 \%$ for filter paper, CM-cellulose, 
laminarin, mannan and pectin, indicating that these substrates might have been contaminated with pentosan, which is susceptible to hydrolysis [14]. Furthermore, Xyl-O1 was completely inactive against the avicel and $p$-nitrophenylglycoside substrates (Table 4).

Table 4. Substrate specificity of purified Aspergillus oryzae Xyl-O1.

\begin{tabular}{|c|c|c|c|}
\hline Substrate & Main chain linkage & Activity $\left(\mathrm{IU} \cdot \mathrm{mL}^{-1}\right)$ & $\begin{array}{c}\text { Purified Xyl-O1 } \\
(\% \text { RA })^{a}\end{array}$ \\
\hline Oat spelt xylan (S) ${ }^{b}$ & $\beta-1,4$ & $0.659 \pm 0.005$ & 100.00 \\
\hline Oat spelt xylan (I) ${ }^{c}$ & $\beta-1,4$ & $0.003 \pm 0.004$ & 0.39 \\
\hline Birchwood xylan (S) & $\beta-1,4$ & $0.560 \pm 0.011$ & 85.03 \\
\hline Birchwood xylan (I) & $\beta-1,4$ & $0.228 \pm 0.025$ & 34.60 \\
\hline Beechwood xylan (S) & $\beta-1,4$ & $0.556 \pm 0.030$ & 84.38 \\
\hline Beechwood xylan (I) & $\beta-1,4$ & $0.024 \pm 0.030$ & 3.58 \\
\hline 4-O-methyl-glucurono-D-xylan (I) & $\beta-1,4$ & $0.328 \pm 0.028$ & 49.87 \\
\hline Filter paper & $\beta-1,4$ & $0.010 \pm 0.007$ & 1.46 \\
\hline CM-cellulose & $\beta-1,4$ & $0.045 \pm 0.004$ & 6.82 \\
\hline Avicel & $\beta-1,4$ & $0.000 \pm 0.002$ & 0.00 \\
\hline Laminarin & $\beta-1,3$ & $0.039 \pm 0.018$ & 5.93 \\
\hline Pectin & $\beta-1,4$ & $0.024 \pm 0.019$ & 3.62 \\
\hline Mannan & $\beta-1,4$ & $0.002 \pm 0.003$ & 0.37 \\
\hline PNPX & PNP- $\beta-1,4$ & $0.000 \pm 0.000$ & 0.00 \\
\hline PNPA & PNP- $\alpha-1,4$ & $0.000 \pm 0.000$ & 0.00 \\
\hline PNPG & PNP- $\beta-1,4$ & $0.000 \pm 0.000$ & 0.00 \\
\hline PNPM & PNP- $\beta-1,4$ & $0.000 \pm 0.000$ & 0.00 \\
\hline
\end{tabular}

${ }^{a}$ Relative activity to oat spelt xylan; ${ }^{b}(\mathrm{~S})$ : Soluble fractions; ${ }^{c}$ (I): Insoluble fractions.

The specificity of Xyl-O1 was determined by analyzing the hydrolysis products of the soluble and insoluble birchwood xylan using the DNS method and HPLC on a Dionex system. The results presented in Table 5 show that the enzyme was more active on the soluble fraction, with a maximum hydrolysis of approximately $33 \%$ obtained after $12 \mathrm{~h}$ of incubation. A similar effect was observed with the insoluble fraction, but the hydrolysis reached only $17.5 \%$. These results are consistent with the observations of Ryan et al. [25], who also found higher rates of hydrolysis for soluble xylan. The preference of Xyl-O1 for the soluble fraction of the substrate may indicate a catalytic efficiency for the branched sites of $O$-acetyl-(4- $O$-methyl-D-glucurono) in the structure of the birchwood xylan. According to Coughlan and colleagues, certain constituents in the structure of the xylan act as binding sites for the catalytic activity of some xylanases [11]. The residues that comprise these sites in the branching structure were partially removed during the preparative alkaline and acid extractions that were performed on the soluble and insoluble fractions of the substrate. However, as shown in Table 5, we observed that 18 - and $24 \mathrm{~h}$ hydrolysis periods did not increase the amount of reducing sugar that was released. It is possible that Xyl-O1-promoted hydrolysis is more efficient after $12 \mathrm{~h}$ and represents a plateau of activity that remains constant for longer incubations. 
Table 5. Hydrolysis of soluble or insoluble birchwood xylan catalyzed by purified Xyl-O1.

\begin{tabular}{ccccc}
\hline & \multicolumn{2}{c}{ Soluble } & \multicolumn{2}{c}{ Insoluble } \\
\cline { 2 - 5 } Hydrolysis time (h) & $\begin{array}{c}\text { Specific reducing } \\
\text { sugar }(\mathbf{m g}) *\end{array}$ & Hydrolysis $(\%)$ & $\begin{array}{c}\text { Specific reducing } \\
\text { sugar }(\mathbf{m g})\end{array}$ & $\begin{array}{c}\text { Hydrolysis } \\
\text { (\%) }\end{array}$ \\
\hline 0 & $0.000 \pm 0.000$ & 0.00 & $0.031 \pm 0.006$ & 1.55 \\
6 & $0.434 \pm 0.011$ & 21.72 & $0.209 \pm 0.036$ & 10.47 \\
12 & $0.667 \pm 0.029$ & 33.35 & $0.351 \pm 0.057$ & 17.54 \\
18 & $0.554 \pm 0.025$ & 27.69 & $0.345 \pm 0.039$ & 17.23 \\
24 & $0.554 \pm 0.025$ & 27.70 & $0.350 \pm 0.037$ & 17.50 \\
\hline
\end{tabular}

Reaction mixtures (final volume of $0.3 \mathrm{~mL}$ ) containing $1 / 3$ purified Xyl-O1 $\left(6.0 \mu \mathrm{g} \cdot \mathrm{mL}^{-1}\right)$ and $2 / 3$ substrate solution with soluble or insoluble birchwood xylans $\left(10 \mathrm{mg} \cdot \mathrm{mL}^{-1}\right)$ were incubated at $28{ }^{\circ} \mathrm{C}$ with agitation at $120 \mathrm{rpm}$. * The amount of the reducing sugar released was estimated by the DNS method.

The identification and quantitative analysis of the soluble xylooligosaccharides that were released seem to indicate that the enzyme catalyzes the random cleavage of internal glycosidic linkages in the soluble and insoluble fractions of the birchwood xylan (Table 6). A similar activity has been described for other enzymes, including the endo- $\beta-1,4-x y l a n a s e s$ produced by Penicillium capsulatum [25], Cephalosporium sp. RYM-202 strain [38], A. fumigatus Fresenius [34] and Acrophialophora nainiana [33]. As shown in Table 6, the hydrolysis products X2-X6 predominated during the first $12 \mathrm{~h}$ of incubation. During the subsequent $12 \mathrm{~h}$, either the X4-X6 xylooligomers predominated, or it was not possible to identify the products, as shown for the insoluble fraction after $24 \mathrm{~h}$ (Table 6). The decreased identification or quantification of the hydrolysis products by HPAEC-PAD indicated the accumulation of higher xylooligomers after the elution of the xylohexaose standard primarily during incubation periods of 18 and $24 \mathrm{~h}$ (results not shown). This suggests that the purified Xyl-O1 is involved in transglycosylation reactions at certain times. In this case, the chromatographic profile showed irregular peaks presenting more intense electrochemical signals and longer retention times than those of established xylooligomers patterns. Because only xylooligosaccharides containing six or fewer xylose units could be detected with the selected chromatographic parameters, we postulated that the products with a higher degree of polymerization (DP) could not be identified by the absence of xylooligomer patterns with longer retention times. With regard to the highest hydrolysis percentage obtained with the DNS method, we hypothesize that the identification of the hydrolysis products by their retention times results in greater specificity. Conversely, the detection of reducing sugars by the DNS method, even using xylose as reference, would not distinguish between the reducing ends of the xylose or more complex xylooligomers. Indeed, the effect of transglycosylation could explain the constant rate of hydrolysis obtained by the DNS method after $12 \mathrm{~h}$ of incubation (Table 5). As reported by Biely and Vranská [47], the transfer of glycosyl groups is a well-known activity of glycosidases and glycanases. Consistent with the findings of these authors, the enzyme acts on oligosaccharides or aryl glycosides (e.g., invertase, $\beta$-galactosidase, $A$. niger $\beta$-glucosidase) to catalyze the formation of various positional isomers of the oligosaccharides. These positional isomers retain the configuration of the glycosidic linkage without specificity for the saccharide acceptor molecule and one particular linkage. For endo-acting glycanases, such as lysozyme, $\alpha$-amylases and cellulases, the specificity is evident, and the same type of glycosidic linkage in the saccharide acceptors is formed from the oligosaccharide glycosyl donors that were cleaved previously. In addition, the xylanase produced by 
Anoxybacillus flavithermus BC [48] catalyzes this transglycosylation activity. In other studies, endo-1,4- $\beta$-xylanases and $\beta$-xylosidases have been used for the synthesis of specific oligosaccharides $[49,50]$ to obtain a cellulose-xylan polymer hybrid [51]. Our results suggest that the transglycosylation reaction catalyzed by Xyl-O1 can occur after a period of effective hydrolysis, in this case, after a $12 \mathrm{~h}$ incubation at $28{ }^{\circ} \mathrm{C}$. However, specific testing of the transglycosylation reaction is required to confirm this hypothesis of Xyl-O1-promoted catalysis. Table 6 shows the general profile of hydrolysis over the 6.0-24 $\mathrm{h}$ incubation period, confirming the predominance of X2 because of the action of Xyl-O1 on the soluble and insoluble fractions of the substrate. For the insoluble and soluble fractions, Xyl-O1 showed a hydrolysis profile with a more relaxed specificity, allowing for the quantification of the products X1 to X6 within six hours of incubation. During this incubation period, xylobiose was the main hydrolysis product released through the activity of the enzyme (Table 6).

Table 6. Identification and quantitative analysis by high-performance anion exchange chromatography coupled with pulsed amperometric detection (HPAEC-PAD) of the xylooligosaccharides released during the hydrolysis reactions catalyzed by purified Xyl-O1.

\begin{tabular}{cccccccccc}
\hline & \multicolumn{3}{c}{ Hydrolysis (\%) Soluble Fraction } & \multicolumn{4}{c}{ Hydrolysis (\%) Insoluble Fraction } \\
\cline { 2 - 9 } $\begin{array}{c}\text { Xylooligosaccharide } \\
\text { products * }\end{array}$ & \multicolumn{3}{c}{ Incubation time (h) } & \multicolumn{4}{c}{ Incubation time (h) } \\
\cline { 2 - 10 } X1 & 0.005 & 0.000 & 0.000 & 0.000 & 0.015 & 0.000 & 0.000 & 0.000 \\
X2 & 0.178 & 0.280 & 0.000 & 0.000 & 0.245 & 0.000 & 0.000 & 0.000 \\
X3 & 0.078 & 0.000 & 0.008 & 0.000 & 0.083 & 0.047 & 0.000 & 0.000 \\
X4 & 0.022 & 0.000 & 0.045 & 0.016 & 0.102 & 0.063 & 0.027 & 0.000 \\
X5 & 0.031 & 0.000 & 0.005 & 0.005 & 0.066 & 0.055 & 0.005 & 0.000 \\
X6 & 0.033 & 0.000 & 0.005 & 0.000 & 0.052 & 0.022 & 0.010 & 0.000 \\
\hline
\end{tabular}

Reaction mixtures (final volume of $0.3 \mathrm{~mL}$ ) containing $1 / 3$ purified Xyl-O1 $\left(6.0 \mu \mathrm{g} \cdot \mathrm{mL}^{-1}\right)$ and $2 / 3$ substrate solution with soluble or insoluble birchwood xylans $\left(10 \mathrm{mg} \cdot \mathrm{mL}^{-1}\right)$ were incubated at $28{ }^{\circ} \mathrm{C}$ with agitation at $120 \mathrm{rpm}$. * Xylose (X1), xylobiose (X2), xylotriose (X3), xylotetraose (X4), xylopentaose (X5) and xylohexaose (X6).

The reduced percentage of X1, especially during the incubation period of $6 \mathrm{~h}$, suggests that Xyl-O1 has an endo-acting mechanism, whereas the predominant hydrolysis product released by Xyl-O1 was $\mathrm{X} 2$, corresponding to $0.458 \%$ in the range of 6 to $12 \mathrm{~h}$ for the soluble fraction and $0.245 \%$ for the insoluble fraction after $12 \mathrm{~h}$ of incubation (Table 6). Additionally, the total hydrolysis percentages obtained by the release of X4, X5 and X6 from the insoluble fraction were $0.192,0.126$ and $0.084 \%$, respectively, in the range of 6 to $18 \mathrm{~h}$. This result shows that the purified Xyl-O1 presents catalytic flexibility by acting on both soluble and insoluble substrates.

\section{Conclusions}

The use of agro-industrial PDCR as a carbon source for the submerged cultivation of $A$. oryzae is a viable and inexpensive alternative for the production of holocellulose-degrading enzymes, mainly xylanases. A low-molecular-weight xylanase was purified and characterized using standard assays. Xyl-O1 was optimally active at $50{ }^{\circ} \mathrm{C}$ and $\mathrm{pH}$ 6.0. It seems to belong to the group of xylanases with an 
endo-acting mechanism. This xylanase hydrolyzed preferentially xylan as the substrate, being an attractive enzyme for potential future applications in the pulp and paper industries. The lignocellulosic biomass contained in the agro-industrial residues, such as PDCR, may enable the efficient production of enzymes at a low cost, thereby reducing the financial support necessary to apply these catalysts to biotechnology.

\section{Acknowledgments}

Edivaldo Ximenes Ferreira Filho acknowledges the receipt of a research fellowship from the Brazilian Research Council (CNPq). This work was funded by CNPq (research grants 563260/2010-6 and 563823/2010-0), the Foundation for Research Support of the Federal District (Brazil, Pronex Program) and the National Institute of Science and Technology of Bioethanol.

\section{References}

1. Howard, R.L.; Abotsi, E.; van Rensburg, E.L.J.; Howard, S. Lignocellulose biotechnology: Issues of bioconversion and enzyme production. Afr. J. Biotechnol. 2003, 2, 602-619.

2. Andreaus, J.; Filho, E.X.F.; Bon, E.P.S. A Review on Biotechnology of Holocellulose-Degrading Enzymes. In Biocatalysis and Bioenerggy; Hou, C.T., Shaw, J.F., Eds.; John Wiley \& Sons, Inc.: Hoboken, NJ, USA, 2008; pp. 195-229.

3. Siqueira, F.G.; Siqueira, E.G.; Jaramillo, P.M.D.; Silveira, M.H.L.; Andreaus, J.; Couto, F.A.; Batista, L.R.; Filho, E.X.F. The potential of agro-industrial residues for production of holocellulase from filamentous fungi. Int. Biodeterior. Biodegrad. 2010, 64, 20-26.

4. Csiszár, E.; Szakács, G.; Rusznák, I. Combining traditional cotton scouring with cellulase enzymatic treatment. Text. Res. J. 1998, 68, 163-167.

5. Csiszár, E.; Urbánszki, K.; Szakács, G. Biotreatment of desized cotton fabric by commercial cellulase and xylanase enzymes. J. Mol. Catal. B 2001, 11, 1065-1072.

6. Turner, P.; Mamo, G.; Karlsson, E. Potential and utilization of thermophiles and thermostable enzymes in biorefining. Microb. Cell. Fact. 2007, 6, 1-23.

7. Murthy, P.; Naidu, M. Production and application of xylanase from Penicillium sp. utilizing coffee by-products. Food Bioprocess Technol. 2010, 5, 657-664.

8. Polizeli, M.L.T.M.; Rizzatti, A.C.S.; Monti, R.; Terenzi, H.F.; Jorge, J.A.; Amorim, D.S. Xylanases from fungi: Properties and industrial applications. Appl. Microbiol. Biotechnol. 2005, 67, 577-591.

9. Salles, B.C.; Cunha, R.B.; Fontes, W.; Sousa, M.V.; Ferreira-Filho, E.X. Purification and characterization of a new xylanase from Acrophialophora nainiana. J. Biotechnol. 2000, 81, 199-204.

10. Vries, R.P.; Visser, J. Aspergillus enzymes involved in degradation of plant cell wall polysaccharides. Microbiol. Mol. Biol. Rev. 2001, 65, 497-522.

11. Cardoso, O.A.V.; Filho, E.X.F. Purification and characterization of a novel cellulase-free xylanase from Acrophialophora nainiana. FEMS Microbiol. Lett. 2003, 223, 309-314.

12. Kobayashi, T.; Abe, K.; Asai, K.; Gomi, K.; Juvvadi, P.R.; Kato, M.; Kitamoto, K.; Takeuchi, M.; Machida, M. Genomics of Aspergillus oryzae. Biosci. Biotechnol. Biochem. 2007, 71, 646-670. 
13. Maeda, H.; Yamagata, Y.; Abe, K.; Hasegawa, F.; Machida, M.; Ishioka, R.; Gomi, K.; Nakajima, T. Purification and characterization of a biodegradable plastic-degrading enzyme from Aspergillus oryzae. Appl. Microbiol. Biotechnol. 2005, 67, 778-788.

14. Filho, E.X.F.; Puls, J.; Coughlan, M.P. Biochemical characteristics of two endo- $\beta-1,4$-xylanases produced by Penicillium capsulatum. J. Ind. Microbiol. Biotechnol. 1993, 11, 171-180.

15. Miller, G.L. Use of dinitrosalicylic acid reagent for determination of reducing sugar. Anal. Chem. 1959, 31, 426-428.

16. Ghose, T.K. Measurement of cellulase activities. Int. Union Pure Appl. Chem. 1987, 59, 257-268.

17. Ximenes, F.A.; Silveira, F.Q.P.; Filho, E.X.F. Production of $\beta$-xylosidase activity by Trichoderma harzianum strains. Curr. Microbiol. 1996, 33, 71-77.

18. Leatherbarrow, R.J. Enzfitter Manual, a Non-Linear Curve Fitting Program for Windows; Biosoft: London, UK, 1999.

19. Segel, I.H. Effects of $\mathrm{pH}$ and Temperature. In Enzyme Kinetics-Behavior and Analysis of Rapid Equilibrium and Steady-State Enzyme Systems; John Wiley \& Sons, Inc.: New York, NY, USA, 1993; pp. 885-942.

20. Bradford, M.M. A rapid and sensitive method for the quantitation of microgram quantities of protein utilizing the principle of protein-dye binding. Anal. Biochem. 1976, 72, 248-254.

21. Laemmli, U.K. Cleavage of structural proteins during the assembly of the head of bacteriophage T4. Nature 1970, 227, 680-685.

22. Blum, H.; Beier, H.; Gross, H.J. Improved silver staining of plant proteins, RNA and DNA in polyacrylamide gels. Electrophoresis 1987, 8, 93-99.

23. Sunna, A.; Puls, J.; Antranikian, G. Characterization of the xylanolytic enzyme system of the extreme thermophilic anaerobic bacteria Thermotoga maritima, T. neapolitana, and T. thermarum. Comp. Biochem. Physiol. A 1997, 118, 453-461.

24. Noronha, E.F.; Ulhoa, C.J. Characterization of a 29-kDa $\beta$-1,3-glucanase from Trichoderma harzianum. FEMS Microbiol. Lett. 2000, 183, 119-123.

25. Ryan, S.E.; Nolan, K.; Thompson, R.; Gubitz, G.M.; Savage, A.V.; Tuohy, M.G. Purification and characterization of a new low molecular weight endoxylanase from Penicillium capsulatum. Enzyme Microb. Technol. 2003, 33, 775-785.

26. Adsul, M.G.; Ghule, J.E.; Singh, R.; Shaikh, H.; Bastawde, K.B.; Gokhale, D.V.; Varma, A.J. Polysaccharides from bagasse: Applications in cellulase and xylanase production. Carbohydr. Polym. 2004, 57, 67-72.

27. Gawande, P.V.; Kamat, M.Y. Production of Aspergillus xylanase by lignocellulosic waste fermentation and its application. J. Appl. Microbiol. 1999, 87, 511-519.

28. Chipeta, Z.; du Preez, J.; Szakacs, G.; Christopher, L. Xylanase production by fungal strains on spent sulphite liquor. Appl. Microbiol. Biotechnol. 2005, 69, 71-78.

29. Chipeta, Z.; du Preez, J.; Christopher, L. Effect of cultivation $\mathrm{pH}$ and agitation rate on growth and xylanase production by Aspergillus oryzae in spent sulphite liquor. J. Ind. Microbiol. Biotechnol. 2008, 35, 587-594.

30. Kronbauer, E.A.W.; Peralta, R.M.; Osaku, C.A.; Kadowaki, M.K. Xylanase production by Aspergillus casielus induced with different carbon sources. Bol. Cent. Pesqui. Process Aliment. 2007, 25, 207-216. 
31. Isil, S.; Nilufer, A. Investigation of factors affecting xylanase activity from Trichoderma harzianum 1073 D3. Braz. Arch. Biol. Technol. 2005, 48, 187-193.

32. Wong, K.K.; Tan, L.U.; Saddler, J.N. Multiplicity of beta-1,4-xylanase in microorganisms: Functions and applications. Microbiol. Rev. 1988, 52, 305-317.

33. Ximenes, F.A.; Sousa, M.V.; Puls, J.; da Silva, F.G.; Filho, E.X.F. Purification and characterization of a low-molecular-weight xylanase produced by Acrophialophora nainiana. Curr. Microbiol. 1999, 38, 18-21.

34. Silva, C.H.C.; Puls, J.; Sousa, M.V.; Filho, E.X.F. Purification and characterization of a low molecular weight xylanase from solid-state cultures of Aspergillus fumigatus Fresenius. Rev. Microbiol. 1999, 30, 114-119.

35. Poutanen, K. An $\alpha$-L-arabinofuranosidase of Trichoderma reesei. J. Biotechnol. 1988, 7, 271-281.

36. Fang, H.-Y.; Chang, S.-M.; Lan, C.-H.; Fang, T.J. Purification and characterization of a xylanase from Aspergillus carneus M34 and its potential use in photoprotectant preparation. Process Biochem. 2008, 43, 49-55.

37. Panagiotou, G.; Olsson, L. Effect of compounds released during pretreatment of wheat straw on microbial growth and enzymatic hydrolysis rates. Biotechnol. Bioeng. 2007, 96, 250-258.

38. Kang, M.; Maeng, P.; Rhee, Y. Purification and characterization of two xylanases from alkalophilic Cephalosporium sp. strain RYM-202. Appl. Environ. Microbiol. 1996, 62, 3480-3482.

39. Teixeira, R.S.S.; Siqueira, F.G.; Souza, M.V.; Filho, E.X.F.; Bon, E.P.S. Purification and characterization studies of a thermostable $\beta$-xylanase from Aspergillus awamori. J. Ind. Microbiol. Biotechnol. 2010, 37, 1041-1051.

40. Kimura, T.; Suzuki, H.; Furuhashi, H.; Aburatani, T.; Morimoto, K.; Karita, S.; Sakka, K.; Ohmiya, K. Molecular cloning, overexpression, and purification of a major xylanase from Aspergillus oryzae. Biosci. Biotechnol. Biochem. 2000, 64, 2734-2738.

41. Sandrim, V.C.; Rizzatti, A.C.S.; Terenzi, H.F.; Jorge, J.A.; Milagres, A.M.F.; Polizeli, M.L.T.M. Purification and biochemical characterization of two xylanases produced by Aspergillus caespitosus and their potential for kraft pulp bleaching. Process Biochem. 2005, 40, 1823-1828.

42. Soren, D.; Jana, M.; Sengupta, S.; Ghosh, A. Purification and characterization of a low molecular weight endo-xylanase from mushroom Termitomyces clypeatus. Appl. Biochem. Biotechnol. 2010, $162,373-389$.

43. Carmona, E.C.; Fialho, M.B.; Buchgnani, É.B.; Coelho, G.D.; Brocheto-Braga, M.R.; Jorge, J.A. Production, purification and characterization of a minor form of xylanase from Aspergillus versicolor. Process Biochem. 2005, 40, 359-364.

44. Keskar, S.S.; Srinivasan, M.C.; Deshpande, V.V. Chemical modification of a xylanase from a thermotolerant Streptomyces. Evidence for essential tryptophan and cysteine residues at the active site. Biochem. J. 1989, 261, 49-40.

45. Marui, M.; Nakanishi, K.; Yasui, T. Chemical modification of xylanases from Streptomyces sp. Biosci. Biotech. Biochem. 1993, 57, 662-663.

46. Christov, L.P.; Szakacs, G.; Balakrishnan, H. Production, partial characterization and use of fungal cellulase-free xylanases in pulp bleaching. Process Biochem. 1999, 34, 511-517. 
47. Biely, P.; VrŠAnskÁ, M. Synthesis and hydrolysis of 1,3- $\beta$-xylosidic linkages by endo-1,4- $\beta$ xylanase of Cryptococcus albidus. Eur. J. Biochem. 1983, 129, 645-651.

48. Kambourova, M.; Mandeva, R.; Fiume, I.; Maurelli, L.; Rossi, M.; Morana, A. Hydrolysis of xylan at high temperature by co-action of the xylanase from Anoxybacillus flavithermus $\mathrm{BC}$ and

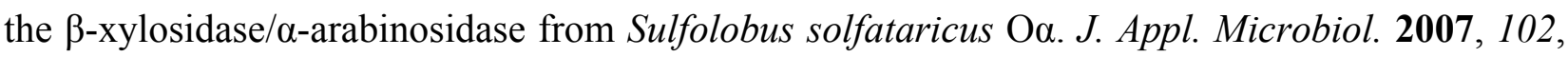
1586-1593.

49. Eneyskaya, E.V.; Brumer, H.; Backinowsky, L.V.; Ivanen, D.R.; Kulminskaya, A.A.; Shabalin, K.A.; Neustroev, K.N. Enzymatic synthesis of $\beta$-xylanase substrates: transglycosylation reactions of the $\beta$-xylosidase from Aspergillus sp. Carbohydr. Res. 2003, 338, 313-325.

50. Jiang, Z.; Zhu, Y.; Li, L.; Yu, X.; Kusakabe, I.; Kitaoka, M.; Hayashi, K. Transglycosylation reaction of xylanase $\mathrm{B}$ from the hyperthermophilic Thermotoga maritima with the ability of synthesis of tertiary alkyl $\beta$-D-xylobiosides and xylosides. J. Biotechnol. 2004, 114, 125-134.

51. Fujita, M.; Shoda, S.-I. Xylanase-catalyzed synthesis of a novel polysaccharide having a glucose-xylose repeating unit, a cellulose-xylan hybrid polymer. J. Am. Chem. Soc. 1998, 120, 6411-6412.

(C) 2012 by the authors; licensee MDPI, Basel, Switzerland. This article is an open access article distributed under the terms and conditions of the Creative Commons Attribution license (http://creativecommons.org/licenses/by/3.0/). 